\title{
Use of anti-tick drugs in dairy farms in the microregion of Alfenas, Minas Gerais, Brazil
}

\author{
Uso de carrapaticidas em fazendas leiteiras na microrregião de Alfenas, \\ Minas Gerais, Brasil
}

Ariane Flávia do Nascimento1* (1); Andressa Santanna Natel²; Laís Maria Viana33; Caroline Lopes de Melo²; Yasmim Gonçalves Lacerda²; Melki Kolbert Lima²; Gabriella Fuzzari Esteves²

\author{
Instituto Federal de Minas Gerais - IFMG, Campus Bambuí, Bambuí, MG, Brasil \\ ${ }^{2}$ Universidade José do Rosário Vellano - UNIFENAS, Alfenas, MG, Brasil \\ ${ }^{3}$ Universidade Federal de Lavras - UFLA, Lavras, MG, Brasil
}

How to cite: Nascimento AF, Natel AS, Viana LM, de Melo CL, Lacerda YG, Lima MK, et al. Use of anti-tick drugs in dairy farms in the microregion of Alfenas, Minas Gerais, Brazil. Braz J Vet Parasito/ 2021; 30(1): e020620. https://doi.org/10.1590/S1984-29612021016

\begin{abstract}
Ectoparasitic infestation in dairy cattle, the most common being Rhipicephalus (Boophilus) microplus, causes significant loss in production. The control of ectoparasites often occurs incorrectly, resulting in resistance to the active ingredients and residues in milk. To understand of acaricide use in the microregion of Alfenas, Minas Gerais (Brazil), questionnaires were applied to the owners of 100 dairy farms in the region and were selected randomly. Dairy farms were allocated according to production scale: up to 150 liters/day, 151-400 liters/day and more than 400 liters/day. The interviewees were asked about production characteristics, acaricide management and active ingredients. The interview answers were subjected to descriptive analysis. Results showed that all properties, independent of production-scale, used acaricides. The most cited was: Cypermethrin Chlorpyrifos Citronellal (31\%), Fluazuron (18.6\%) and Fipronil (17\%). Among the interviewed, $41,1 \%$ use drugs that have restrictions that are not allowed in legislation for use in lactating dairy cows (fluazuron, fipronil, ivermectin). 15\% affirmed they weren't aware of the "withdrawal period" of medication and 73\% change in the active ingredient used. In order to revert this antiparasitic drug's resistance situation and contamination of milk with drug residues, it is necessary to focus on the awareness of milk producers and training of labor.
\end{abstract}

Keywords: Cattle, ectoparasites, residues, resistance, Rhipicephalus (Boophilus) microplus.

\begin{abstract}
Resumo
A infestação por ectoparasitas em bovinos leiteiros, sendo o mais comum o Rhipicephalus (Boophilus) microplus, causa prejuízos significativos na produção. No entanto, o controle dos ectoparasitas geralmente ocorre incorretamente, resultando em resistência aos princípios ativos e presença de resíduos no leite. Para entender os padrões de uso de acaricidas na microrregião de Alfenas, Minas Gerais, Brasil, foram aplicados questionários aos proprietários de 100 fazendas leiteiras que foram classificadas de acordo com uma escala de produção: até 150 litros/dia, de 151 a 400 litros/dia e mais de 400 litros/dia. Os entrevistados foram questionados sobre características da produção, manejo do acaricida de gado e conhecimento sobre os princípios ativos. Todas as propriedades, independentemente da escala de produção, usavam acaricidas. Foram citados com maior frequência: Cipermetrina + Clorpirifós + Citronelal (31\%), Fluazuron (18.6\%) e Fipronil (17\%). Entre os produtores entrevistados, 41,1 \% fazem uso de drogas com restrição que não são atualmente permitidas na legislação para uso em vacas em lactação (fluazuron, fipronil, ivermectina). 15\% dos produtores de leite afirmaram não estar cientes do "período de carência" dos medicamentos; outros relatam trocas constantes do princípio ativo utilizado. Para reverter a situação do uso indiscriminado de antiparasitários, é necessário focar na conscientização dos produtores de leite e na formação do trabalho.
\end{abstract}

Palavras-chave: Bovinos, ectoparasitas, resíduos, resistência, Rhipicephalus (Boophilus) microplus. 


\section{Introduction}

Minas Gerais, a state located in Southeastern Brazil, has the largest milk production in the country. During the first trimester of 2019, the state processed 1,566,954 liters of this product, leading the milk purchase ranking from dairy companies (EMBRAPA, 2019).

In order to obtain greater production, it is necessary to control the environmental factors that might negatively affect the herd. The infestation by ectoparasites determines a greater reduction in the productive indexes since, in addition to poor weight gain, milk production and animal welfare, it transmits pathogens that increase the occurrence of diseases (Fraga et al. 2003; Pereira \& Labruna, 2008).

The cattle tick, Rhipicephalus (Boophilus) microplus, is responsible for an annual economic impact of 3.24 billion dollars in Brazil, and for 2.7\% reduction in the milk production of Minas Gerais (Grisi et al., 2014; Rodrigues \& Leite, 2013). Rhipicephalus (Boophilus) microplus can be found mainly in areas of tropical climate, and is a one-host parasite. The cycle happens in two different phases: the non-parasitic phase occurs when the engorged female detaches from the host, falls and starts laying eggs. The parasitic phase takes place when the young ticks are already in their parasitic phase and consequently attach themselves to the host.

The comprehension of this biological cycle is important for the accomplishment of an effective and strategical control of the ticks. However, research carried out in Brazil showed that the majority of producers have no knowledge of this cycle, fomenting the indiscriminate and unregulated use of antiparasitic drugs (EMBRAPA, 2003; Veríssimo et al., 2016), or few know the form of strategic control and none use it correctly (Rocha et al., 2006).

Brazil has registered 380 different veterinary products in Ministry of Agriculture, Livestock and Food Supply (MAPA) used to combat ticks, formulated with 15 active ingredients from 9 different chemical classes (SIDAN, 2017). This fact can make it difficult for the producer to choose a new product. There is little technical knowledge available, both on the part of the producers and the clerks of agricultural houses, in order to know, at the time of choice, the differences in the forms of action of the products that enable them to make the right decision (Furlong et al., 2007). The indiscriminate rotation without criteria of products can favor the selection of individuals tolerant to all these products and, in this situation, the resistance process can be underway (Furlong et al., 2007).

Knowledge of practices adopted in the tick control properties is important to help the researcher design more viable control methods and to assist the producer in the introduction of these methodologies in the field (Bertolucci, 2011), as done by Jonsson \& Matschoss (1998) and the Dairy TickCON program in Australia, encouraging producers to adopt methods that minimize the use of chemicals and maximize their effectiveness.

The production factor can positively influence the control of Rhipicephalus (Boophilus) microplus. Less productive properties with less educated owners were where ticks were found with more frequency, promoting greater pressure for the selection of resistant ticks (Rocha et al., 2006).

The growing phenomenon of resistance to the active ingredients used and the presence of residues in milk or meat are some of the most important and damaging aspects resulting from the use of acaricides on a larger scale (Fraga et al., 2003; Veríssimo et al., 2016). Thus, the aim of this study was to understand the perception of milk producers of three scaled-productions of the micro region of Alfenas, Minas Gerais (Brazil) about the use of acaricides.

\section{Material and Methods}

The experiment was carried out in the micro region of Alfenas, south of the State of Minas Gerais, Brazil (Figure 1). The micro region is formed by 12 cities (Alfenas, Alterosa, Areado, Carmo do Rio Claro, Carvalhópolis, Conceição da Aparecida, Divisa Nova, Fama, Machado, Paraguaçu, Poço Fundo and Serrania). In the region, there are 4,313 milk producing establishments and a bovine herd of 40,871 milk cows (IBGE, 2017).

The information was obtained through semi-structured questionnaires (Figure 2) applied in-person to 100 owners of dairy establishments. All procedures involving humans were approved by the Research Ethics Committee of UNIFENAS (protocol number 2746625, Plataforma Brazil). Prior to the application of the questionnaires, the participants signed the Free and Informed Consent Term and the research was classified as low risk (Resolution 196/96).

The selection of milk producing establishments was carried out by simple occasional sampling in the defined region independent of daily production scale. Property names were omitted. 


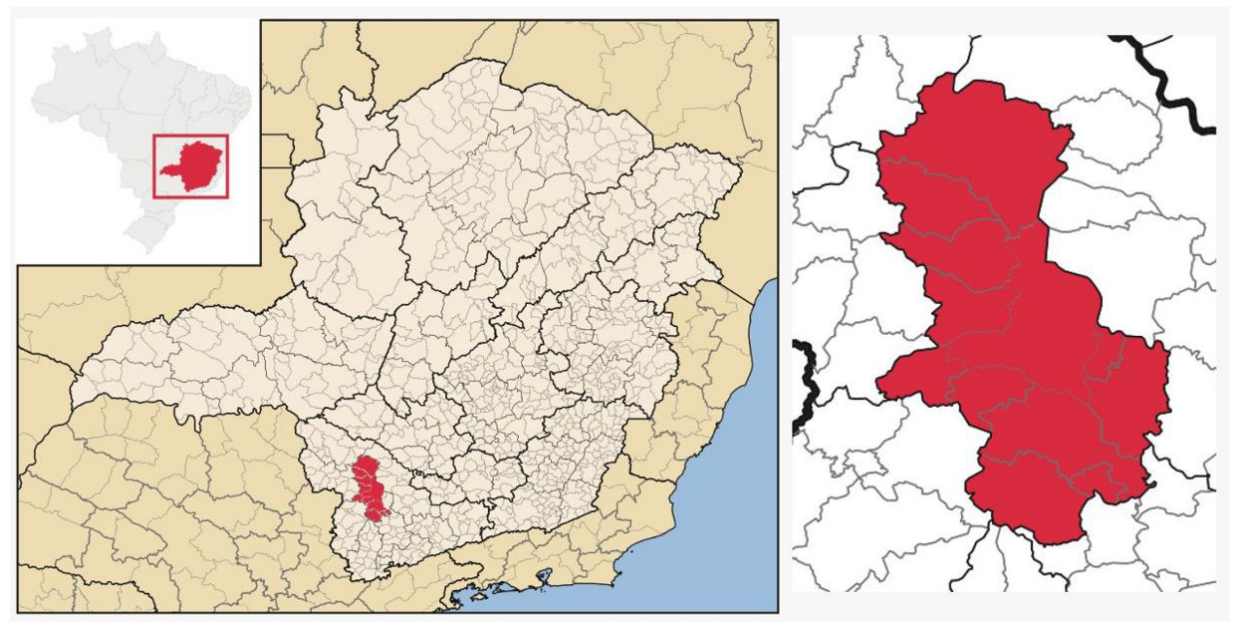

Figure 1. The micro region of Alfenas, south of the State of Minas Gerais, Brazil.

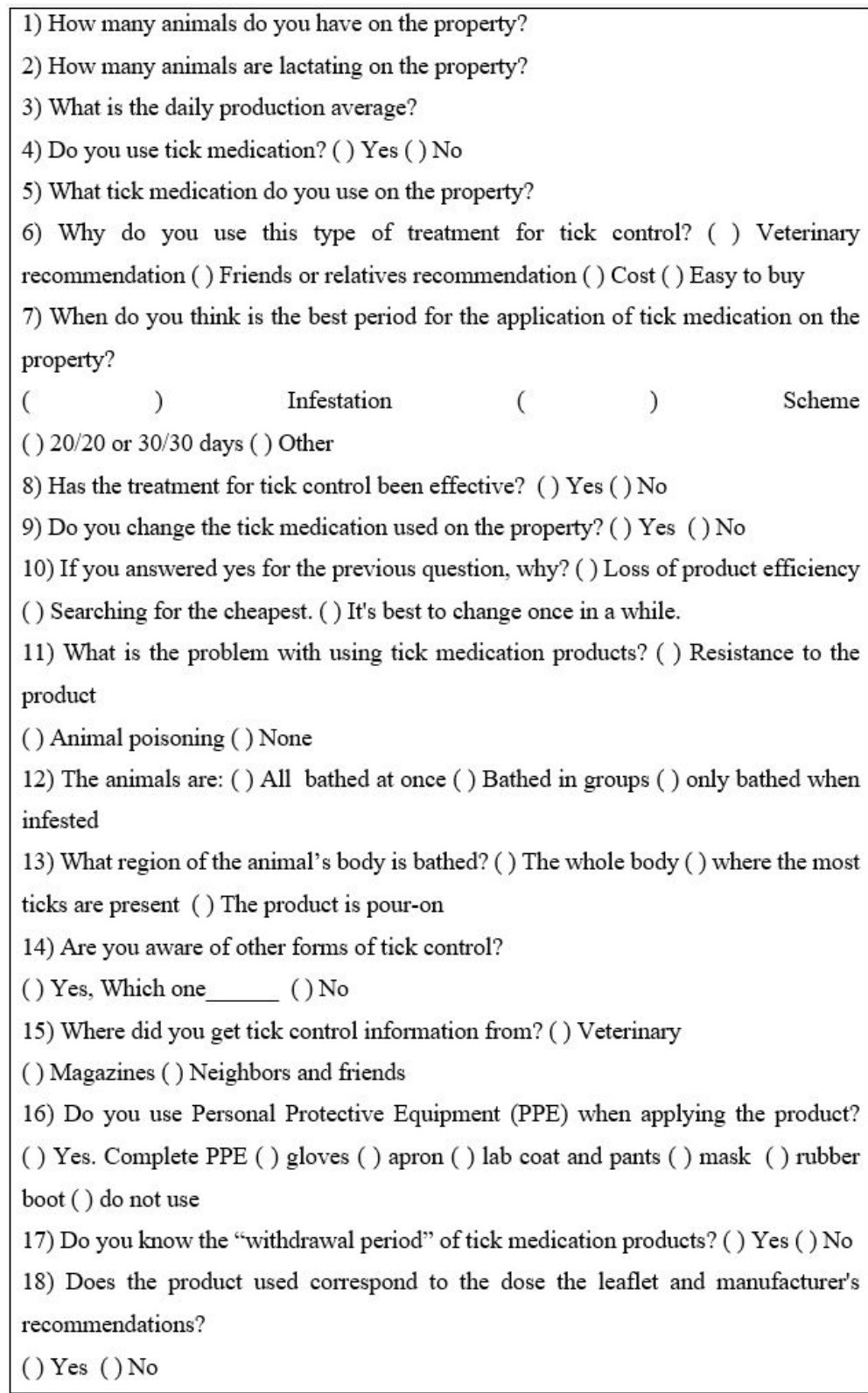

Figure 2. Questionnaire applied to 100 dairy farms in Southern Minas Gerais from August 2017 to May 2018. 
To analyze the influence of the production scale by the management of ectoparasites, the 100 milk producing establishments were allocated to one of the three production strata: small, medium and large, characterized by daily milk production of less than $151 \mathrm{~kg}$, from 151 to $400 \mathrm{~kg}$ and over $400 \mathrm{~kg}$, respectively, as proposed by Lopes et al. (2006).

The producers were questioned about the total number of cattle, number of lactating cows, average daily production and animal productivity. Regarding the management of ectoparasites, the type of drug used on their cattle was elevated (accepting more than one answer). The application form questions the effectiveness of the chosen treatment, if they changed the active ingredient frequently, handling the tick and the person responsible for the indication of the active ingredient. When the commercial name was mentioned, the package insert was consulted to confirm the active ingredient mentioned in the medication formula to catalog the data. In addition, they were also questioned about any knowledge of the "withdrawal period" of the medication they were using and the instructions on the package insert were followed.

Out of the evaluated population of 4,313 establishments, 100 were sampled at random, that is, $2.3 \%$ of the population. The open responses were categorized through content analysis (Minayo, 1993), thus, each question was transformed into a variable, mostly nominal qualitative. Subsequently, descriptive statistical analysis using frequency (Gil, 1991) was performed and a chi-square test was done to assess the influence of the production scale. Anova analysis of variance was performed for the productive variables (number of cows, milk production and productivity), with Tukey's test at 5\% probability.

\section{Results}

The survey participants were owners responsible for 100 milk producing establishments, 39\% of which were small-scale (up to 151 liters / day); 24 medium-scale production (151 to 400 liters/day) and 37 produced more than 400 liters per day, classified as large-scale production. On average, the herds had 150 cows (Median = 70, SD =277.5), with an average of 50 lactating animals (Median $=25$; SD $=86.6$ ). The average daily production was 973.7 liters (Median = 225; SD = 2278.3 liters), while productivity was 13.1 liters per cow per day (Median = 10, SD = 7.4 liters per cow per day).

There was a statistical difference $(P>0.01)$ between the establishments evaluated for the variables of total cows, lactating cows, daily production and animal productivity (Table 1), which is related to the production scale. Large-scale production properties showed, on average, a higher number of cows (292), lactating cows (109) and, consequently, higher milk production (2443.5 liters / day) and productivity (20.9 liters / cow / day) when comparing small scale properties (66 cows, 8 in lactation, 58.1 liters / day and 7.2 liters / cow / day) and medium scale productions (71 cows, 25 in lactation, 256.5 liters / day and 10.7 liters / cow / day) that did not differ.

Of the 100 (one hundred) dairy farms that answered the questionnaire, all of them used at least one or more types of tick medicament products and 129 active ingredient responses were obtained (Table 1). The most used acaricides were a mixture of Cypermethrin + Chlorpyrifos + Citronellal $31 \%(n=40)$, followed by Fluazuron 18.6\% $(n=24)$, Fipronil 17\% $(n=22)$ and Amitrax 10.8\% ( $n=14)$ (Table 2). The production scale did not interfere with the choice

Table 1. Profile of milk producing establishments participating in the survey in relation to the scale of milk production (small up to 151 liters / day; averages 151 to 400 liters and large production greater than 400 liters/day).

\begin{tabular}{|c|c|c|c|c|c|c|c|}
\hline \multirow{2}{*}{ Variable } & \multicolumn{3}{|c|}{ Production Scale } & \multirow{2}{*}{ Average } & \multirow{2}{*}{ Median } & \multirow{2}{*}{ DP } & \multirow{2}{*}{ p-value } \\
\hline & Small $(n=39)$ & Medium $(n=24)$ & Large $(n=37)$ & & & & \\
\hline Total cows & $66 b$ & $71 b$ & $292 a$ & 150.0 & 70 & 277.5 & $<0.01$ \\
\hline Lactating Cows & $8 b$ & $25 b$ & $109 a$ & 50.0 & 25 & 86.6 & $<0.01$ \\
\hline Lactating Cows (\%) & 37.2 & 44.5 & 43.9 & 41.4 & 40 & 19.3 & 0.21 \\
\hline Production (L/dia) & $58.1 \mathrm{~b}$ & $256.5 b$ & $2443.7 a$ & 973.7 & 225 & 2278.3 & $<0.01$ \\
\hline Productivity (L/vaca/dia) & $7.2 \mathrm{~b}$ & $10.7 a b$ & $20.9 a$ & 13.1 & 10 & 7.42 & $<0.01$ \\
\hline
\end{tabular}

*DP: standard deviation; n: number of milk producing establishments in each production scale; ${ }^{a, b}$ different letters on the same line differ statistically by the tukey test $5 \%$ probability. 
Table 2. Active ingredient of the products used; chemical class of each product; frequency of use in $100^{*}$ dairy farms in the southern region of Minas Gerais.

\begin{tabular}{|c|c|c|c|c|c|c|c|c|c|c|}
\hline \multirow{3}{*}{ Active Ingredient } & \multirow{3}{*}{ Chemical Class } & \multicolumn{6}{|c|}{ Production Scale** } & \multirow{2}{*}{\multicolumn{2}{|c|}{$\begin{array}{l}\text { Total } \\
(n=129)\end{array}$}} & \multirow{3}{*}{ p-value } \\
\hline & & \multicolumn{2}{|c|}{$\begin{array}{l}\text { Small } \\
(n=44)\end{array}$} & \multicolumn{2}{|c|}{$\begin{array}{l}\text { Medium } \\
(n=28)\end{array}$} & \multicolumn{2}{|c|}{$\begin{array}{l}\text { Large } \\
(n=57)\end{array}$} & & & \\
\hline & & $\mathrm{fa}$ & $\operatorname{fr}(\%)$ & fa & $\operatorname{fr}(\%)$ & $\mathbf{F a}$ & $\operatorname{fr}(\%)$ & fa & fr (\%) & \\
\hline Amitraz & Amidines & 3 & $6.8 \%$ & 3 & $10.7 \%$ & 8 & $14 \%$ & 14 & $10.9 \%$ & \multirow{10}{*}{0.161} \\
\hline $\begin{array}{c}\text { Cypermethrin } \\
+ \text { Chlorpyrifos+Citronella }\end{array}$ & Pyrethroid+organophosphate & 15 & $34.1 \%$ & 13 & $46.4 \%$ & 12 & $21.1 \%$ & 40 & $31 \%$ & \\
\hline Cypermethrin & \multirow{2}{*}{ Pyrethroid } & 4 & $9.1 \%$ & 1 & $3.6 \%$ & 5 & $8.8 \%$ & 10 & $7.8 \%$ & \\
\hline Deltamethrin & & 6 & $13.6 \%$ & 1 & $3.6 \%$ & 1 & $1.8 \%$ & 8 & $6.2 \%$ & \\
\hline Diflubenzuron & \multirow{2}{*}{ Benzoylphenyl urea } & 1 & $2.3 \%$ & & $0 \%$ & & $0 \%$ & 1 & $0.8 \%$ & \\
\hline Fluazuron & & 6 & $13.6 \%$ & 2 & $7.1 \%$ & 16 & $28.1 \%$ & 24 & $18.6 \%$ & \\
\hline Fipronil & Phenylpyrazoles & 5 & $11.4 \%$ & 6 & $21.4 \%$ & 11 & $19.3 \%$ & 22 & $17.1 \%$ & \\
\hline Ivermectin & Macrocyclic lactones & 3 & $6.8 \%$ & & $0 \%$ & 4 & $7 \%$ & 7 & $5.4 \%$ & \\
\hline Trichlorfon & Organochlorophosphate & 1 & $2.3 \%$ & 1 & $3.6 \%$ & & $0 \%$ & 2 & $1.6 \%$ & \\
\hline Other & & & $0 \%$ & 1 & $3.6 \%$ & & $0 \%$ & 1 & $0.8 \%$ & \\
\hline
\end{tabular}

*Each owner could name more than one frequently used acaricide; **fa: Absolute frequency; fr: Relative frequency.

of the medication used $(P=0.229)$. As for the "withdrawal period", $15 \%$ of milk producers answered that they did not have knowledge of the "withdrawal period" of tick medicament used in their dairy herd and $9 \%$ answered that they did not use tick medication products according to the dose manufacturer's recommendations (Table 3), small-scale producers are the ones who least consult the package insert for the medication $(P=0.02)$.

The variables choice of acaricides, problems with the use of acaricides, use of the recommended dose, change of acaricides and use of personal protective equipment (PPE) during application were influenced by the production scale $(P<0.05)$ according to the chi-square test (Table 3$)$.

The veterinary recommendation is the main reason for choosing acaricides in $46.2 \%(n=18)$ of small-scale properties and $73 \%(n=27)$ of large-scale properties. $41.7 \%(n=10)$ of the medium-scale production properties choose acaricides based on recommendations of friends or relatives.

The moment of application most used in the 100 properties is during the infestation $(n=47)$, and in 36 establishments the application is made in lots and the acaricide is applied to the whole body $(n=46)$ or pour-on $(n=44)$.

The answers related to the problems with the use of acaricides was influenced by the production scale $(P=0.017)$. $78.4 \%(n=29)$ of the respondents of large-scale properties reported that resistance was the main problem. Differently, $56.4 \%(n=22)$ of the owners of small-scale establishments responded that they had no problems.

Of the 100 milk producers, 73 said they had already changed their active ingredient, with large-scale producers having changed the most, $89.2 \%(n=33)$.

The production scale influenced $(P=0.016)$ the response on the use of PPE. The majority of respondents $(41 / 100)$ stated that they used incomplete PPE at the time of application of the acaricide, followed by those who claimed (31/100) that they did not use any equipment and only 28 establishments made complete use of PPE, 14 of which were of large-scale production, 8 medium and 6 small-scale. The majority of small-scale production owners, $48.7 \%(n=19)$ responded that they did not use any PPE equipment.

\section{Discussion}

Although the properties participating in the study differed in cattle numbers, production and productivity, due to their production scales (Table 1), they showed to be above the average in productivity indexes of the State of Minas Gerais of 5.9 liters per cow per day (IBGE, 2017). 
Table 3. Variables related to the use of acaricides according to the scale of production of dairy properties of micro region of Alfenas, south of the State of Minas Gerais, Brazil.

\begin{tabular}{|c|c|c|c|c|c|c|c|c|c|}
\hline \multirow{3}{*}{ Variable } & & \multicolumn{6}{|c|}{ Production Scale* } & \multirow{3}{*}{$\begin{array}{c}\text { Total } \\
(n=100)\end{array}$} & \multirow{3}{*}{ p-value } \\
\hline & & \multicolumn{2}{|c|}{$\begin{array}{l}\text { Small } \\
(n=39)\end{array}$} & \multicolumn{2}{|c|}{$\begin{array}{l}\text { Medium } \\
(n=24)\end{array}$} & \multicolumn{2}{|c|}{$\begin{array}{l}\text { Large } \\
(n=37)\end{array}$} & & \\
\hline & & fa & $\mathrm{fr}$ & $\mathrm{fa}$ & $\mathrm{fr}$ & fa & $\mathrm{fr}$ & & \\
\hline \multirow{4}{*}{ Choice of acaricide } & Veterinary & 18 & $46.2 \%$ & 8 & $33.3 \%$ & 27 & $73.0 \%$ & $53 \%$ & \multirow{4}{*}{0.021} \\
\hline & Friends/ relatives & 8 & $20.5 \%$ & 10 & $41.7 \%$ & 5 & $13.5 \%$ & $23 \%$ & \\
\hline & Cost & 8 & $20.5 \%$ & 2 & $8.3 \%$ & 2 & $5.4 \%$ & $12 \%$ & \\
\hline & Easy to buy & 5 & $12.8 \%$ & 4 & $16.7 \%$ & 3 & $8.1 \%$ & $12 \%$ & \\
\hline \multirow{4}{*}{ Period for the application } & Infestation & 19 & $48.7 \%$ & 12 & $50.0 \%$ & 16 & $43.2 \%$ & $47 \%$ & \multirow{4}{*}{0.385} \\
\hline & Scheme & 7 & $18.0 \%$ & 3 & $12.5 \%$ & 13 & $35.1 \%$ & $23 \%$ & \\
\hline & $20 / 20$ or $30 / 30$ & 8 & $20.5 \%$ & 5 & $20.8 \%$ & 8 & $21.6 \%$ & $21 \%$ & \\
\hline & Other & 5 & $12.8 \%$ & 4 & $16.7 \%$ & 0 & $0.0 \%$ & $9 \%$ & \\
\hline \multirow{3}{*}{ Treated Animals } & All bathed & 21 & $53.9 \%$ & 12 & $50.0 \%$ & 12 & $32.4 \%$ & $19 \%$ & \multirow{3}{*}{0.215} \\
\hline & Bathed in groups & 13 & $33.3 \%$ & 9 & $37.5 \%$ & 14 & $37.8 \%$ & $36 \%$ & \\
\hline & Infested & 5 & $12.8 \%$ & 3 & $12.5 \%$ & 11 & $29.7 \%$ & $19 \%$ & \\
\hline \multirow{3}{*}{ Region Treated } & Whole body & 19 & $48.7 \%$ & 11 & $45.8 \%$ & 16 & $43.2 \%$ & $46 \%$ & \multirow{3}{*}{0.497} \\
\hline & Pour-on & 14 & $35.9 \%$ & 11 & $45.8 \%$ & 19 & $51.4 \%$ & $44 \%$ & \\
\hline & Other & 6 & $15.4 \%$ & 2 & $8.3 \%$ & 2 & $5.4 \%$ & $20 \%$ & \\
\hline \multirow{3}{*}{ Problems with using } & Resistance & 16 & $41.0 \%$ & 16 & $66.7 \%$ & 29 & $78.4 \%$ & $61 \%$ & \multirow{3}{*}{0.017} \\
\hline & Poisoning & 1 & $2.6 \%$ & 0 & $0.0 \%$ & 1 & $2.7 \%$ & $2 \%$ & \\
\hline & None & 22 & $56.4 \%$ & 8 & $33.3 \%$ & 7 & $18.9 \%$ & $37 \%$ & \\
\hline \multirow{2}{*}{ Recommended dosage used? } & Yes & 31 & $79.5 \%$ & 23 & $95.8 \%$ & 37 & $100 \%$ & $91 \%$ & \multirow{2}{*}{0.026} \\
\hline & No & 8 & $20.5 \%$ & 1 & $4.2 \%$ & 0 & & $9 \%$ & \\
\hline \multirow{3}{*}{$\begin{array}{c}\text { Use Personal Protective } \\
\text { Equipment }\end{array}$} & Complete & 6 & $15.4 \%$ & 8 & $33.3 \%$ & 14 & $37.8 \%$ & $28 \%$ & \multirow{3}{*}{0.016} \\
\hline & Incomplete & 14 & $35.9 \%$ & 9 & $37.5 \%$ & 18 & $48.6 \%$ & $41 \%$ & \\
\hline & None & 19 & $48.7 \%$ & 7 & $29.2 \%$ & 5 & $13.5 \%$ & $31 \%$ & \\
\hline \multirow{2}{*}{ Change of acaricide } & Yes & 24 & $61.5 \%$ & 16 & $65.2 \%$ & 33 & $89.2 \%$ & $73 \%$ & \multirow{2}{*}{0.017} \\
\hline & No & 15 & $38.5 \%$ & 8 & $34.8 \%$ & 4 & $10.8 \%$ & $27 \%$ & \\
\hline \multirow{2}{*}{ Aware of the "withdrawal period } & Yes & 30 & $76.9 \%$ & 20 & $83.3 \%$ & 35 & $94.6 \%$ & $85 \%$ & \multirow{2}{*}{0.094} \\
\hline & No & 9 & $23.1 \%$ & 4 & $16.7 \%$ & 2 & $5.4 \%$ & $15 \%$ & \\
\hline \multirow{2}{*}{ Aware of other forms control } & Yes & 27 & $69.2 \%$ & 20 & $83.3 \%$ & 36 & $97.3 \%$ & $83 \%$ & \multirow{2}{*}{0.160} \\
\hline & No & 12 & $30.8 \%$ & 4 & $16.7 \%$ & 1 & $2.7 \%$ & $17 \%$ & \\
\hline
\end{tabular}

*fa: Absolute frequency; fr: Relative frequency.

The higher productivity observed in large-scale production properties (20.9 liters per cow per day), compared to small scales ( 7.2 liters per cow per day), may be related to genetics and animal management. In this study, the producers were not asked about the genetics of the dairy cattle, but the hypothesis is that the cattle of large producers consist of a greater degree of animals of European blood, Holstein, which are animals of higher production by lactation. Factor that may also have influenced low tick resistance. According to Miranda \& Freitas (2009), the choice of the genetic resource is related to the milk production system. Properties with high milk production per lactation 
(> 8,000 kg) use specialized European breeds, properties with average productivity (3,500 to 6,000 kg / lactation) use crossbred breeds, triple crossbreeding, and properties with milk production below 3,500 kg per lactation use breeds with greater zebu blood.

Some studies show that dairy $B$. taurus $\times$ B. indicus crosses, mainly Girolando cows, prevail in Minas Gerais dairy farms (Madalena et al., 2012; Embrapa, 2019). Crossbreeding has been used to generate cows that would combine the high milk production capacity of Holsteins and the adaptability to tropical conditions of the Gyr breed (Stafuzza et al., 2017).

About the tick resistance, Lemos et al. (1985), when studying and natural infestations in heifers of different genetic groups, which ranged from $1 / 4$ Holstein $x$ Zebu to pure Holstein, a higher parasitic load as the proportion of Holstein genes increased was observed, making this additive effect significant and evidencing the lower resistance of the European breed.

Other factors to consider to increase productivity, according to Faria \& Corsi (1993), are rational use of labor, improvement in reproduction rates, improvement in feed efficiency and improvement in the health status of the herd. Within sanitary management, parasitosis is worth mentioning, which can cause indirect losses, expenses with control, direct losses, decrease in the production and transmission of diseases, which affects animal productivity (Bertolucci, 2011).

Currently, six classes of acaricides can be easily found to purchase in the Brazilian market: phenylprazoles (fipronil), organophosphates, formamidines (amitraz), synthetic pyrethroids, macrocyclic lactones and benzoylphenylureas (fluazuron). The indiscriminate use of acaricides to promote tick control might generate resistant strains of Rhipicephalus (Boophilus) microplus, and it is already mentioned in some studies in Brazil and the world (Leal et al., 2003; Li et al., 2007; Mendes et al., 2011; Fernández-Salas et al., 2012; Miller et al., 2013; Rodríguez-Vivas et al., 2014). The occurrence of resistant ticks leads to an increase of commercialized products that contain two or more compounds in its formulations (Reck et al., 2014).

When asked which acaricide was used on the property, being able to quote more than one product, most milk producers $(31 \%, 40 / 129)$ responded to using products with more than one active ingredient (Cypermethrin + Chlorpyrifos + Citronella) in their composition (Table 2). The pyrethroid-organophosphate association increase efficiency against populations of Rhipicephalus (Boophilus) microplus. Santana (2000) observed higher mean efficiencies of such associated compounds, compared to isolated pyrethrins. Rodrigues et al. (2018) when using a product composed of cypermethrin (15 g) + chlorpyrifos ( $25 \mathrm{~g})+$ citronellal (1 g), observed an average efficacy of 35\% in Brangus animals and 51\% in Nelore cows. Higa et al., (2019) evaluated the effectiveness of the association cypermethrin + chlorpyrifos + piperonylbutoxide, observed a reduction in the number of ticks parasitizing Brangus cows after application. According to Campos \& Oliveira (2005), despite the fact that organophosphates are older products and with reports of resistance worldwide, this chemical group associated with pyrethroids can be used effectively, if a functioning tick management program is implemented.

In addition, cypermethrin (pyrethroid) is an active ingredient that can be found in 81 veterinary products. Its use can result in milk residues; therefore, the withdrawal period must be of at least 14 days (Bastos et al., 2011; Hernandes et al., 2009). However, 15\% (15/100) of milk producers affirmed they weren't aware of the "withdrawal period" of tick medication products they used (Table 3), which can lead to an increase in drug residues in milk.

The majority of milk producers interviewed (41.1\%) claimed to use drugs that are of restricted use in lactating dairy cows (fluazuron (18.6\%) or fipronil (17.1\%) or ivermectin (5.4\%) in their composition (Table 2).

Fluazuron has been in the market since 1994 and the first case of resistance occurred in 2014 (Yessinou et al., 2016). Additionally, this is a lipophilic drug that demands milk fat as an excretion route, resulting in high levels of residues in milk. For this reason, the use of fluazuron is not allowed in lactating or gestational cows in their last trimester (Bull et al., 1996; de Oliveira et al., 2013; Reck et al., 2014).

Other drugs that have active ingredients with milk as an excretion route were mentioned in this study. The avermectins (ivermectin, abamectin, doramectin and eprinomectin) belong to the macrocyclic lactones group, and other than accumulate in milk, they can also be responsible for changes in dairy products, since its base might generally interfere with microrganisms (Whelan et al., 2010).

Fipronil, belonging to the Phenylpyrazoles class (Le Faouder et al., 2007), shows affinity to fat. Spagnol et al. (2010) confirmed that fipronil had greater effectiveness in properties in Itamaraju (Bahia), and the authors justified the high efficiency due to the cost and the fact that its use is prohibited in lactating cows. 
Of the 100 milk producers, 73 said they had already switched active ingredients, with 89.2\% (33/37) of large-scale producers, $65.2 \%(16 / 24)$ of medium-scale and $61.5 \%$ (24/39) of small-scale productions. $68.4 \%$ of those who have already replied that the reason for the change was because of a drop in product efficiency. This results may be related to the genetics of the animals used in the properties, since how many the resistance or susceptibility of these animals is dependent on the proportion of European genes (Lemos et al., 1985) and in high-productivity properties the proportion of Holstein genes increased (Miranda \& Freitas, 2009).

The indiscriminate manner of changing products without criteria favors the selection of resistant tick populations to all active principle. The accelerated development of resistance to an active principle is a problem that has caused great concern in society and government agencies (Leal et al., 2003). In the present work, resistance was the problem pointed out by $61 \%$ (61/100) of the interviewed milk producers, mainly large-scale producers (Table 3 ). Most producers of small-scale properties (56.4\%) stated that they had no problem with the use of acaricides. This answer may be related to the degree of understanding about the mechanism by which the loss of efficiency of tick products occurs and the occurrence of resistance, with little technical knowledge on the part of the producer. Rocha et al. (2006) pointed out the lack of knowledge of the way in which acaricides act by producers in the south of Minas Gerais. In another study, it was observed that properties with low production and productivity demonstrated that they did not have the necessary knowledge to improve the control of ticks or their importance (Rocha, 1995).

One way to improve herd resistance is to through the selection of resistant cattle, since the heritability estimates indicate that the selection for resistance to the parasite can be highly efficient. Therefore, the selection of resistant cattle as a tick control strategy will enable the earlier and punctual identification of genetically superior animals (Biegelmeyer et al., 2012)

According to Andreotti et al. (2019), for more efficient control, some aspects must be considered, among which include: the knowledge of the tick's life cycle and its relationship with variations in environmental conditions. The population dynamics, especially seasonality, is crucial to identify when the tick population is at the most vulnerable stage to carry out treatments with acaricides. European gene level of the animals should also be considered, associated with the type and management of pasture as well as the stocking rate and system.

The choice of acaricides was influenced by the scale of production. $73 \%$ (27/39) of properties with a production greater than 400 liters per day chose their product by the hand of a veterinarian. $41.7 \%(10 / 24)$ of medium-scale properties take into account the indication of friends or relatives and $41 \%(16 / 37)$ of the small-scale properties choose the acaricide by indication of friends, relatives or by the low cost (Table 3). This data corroborates with Rocha (1995) about the lower importance given to the control of ticks by lower production properties.

What determined the timing of application in 47\% (47/100) of dairy farms was the degree of tick infestation, a practice inconsistent with the technical criteria for reducing resistance. According to EMBRAPA (2000) the application of acaricides at the time of infestation favors the high frequency of tick baths, which select and propagate the resistance allele by selection pressure. Rocha et al. (2006) observed that less productive properties were where acaricides were applied more frequently, promoting greater pressure from resistant ticks.

Other inappropriate practices of the use of acaricides can also favor the appearance of resistance in the populations of Rhipicephalus (Boophilus) microplus (Rocha et al., 2006). The use of doses can be classified as inappropriate without meeting the manufacturer's recommendation, being the response of $9 \%(9 / 100)$ of the owners. A difference was observed for the scale of production in this variable, where $20.5 \%(8 / 37)$ of the small-scale properties did not use the recommended dose in the package insert, which reinforces the conclusions of Bertolucci (2011) that in the properties of South Minas Gerais, the control of tick occurs empirically. In addition, this data is worrying, because along with resistance, it can increase residues in milk (Rocha et al., 2006).

The moderate use of acaricides should be a practice on the properties, the solutions should be prepared with the amount of acaricides indicated on the package insert, which should be added to a small amount of water (syrupy liquid), so after the necessary volume of water is added to complete the total amount of the solution to be prepared (Furlong et al., 2007). It is very important to always read the package insert and follow the manufacturer's recommendations.

Acaricides are toxic products that act mainly on the central nervous system, causing allergies, intoxications, organ malformations and tumor growth (Furlong et al., 2007). Thus, the use of PPE (overalls or plastic cover, mask, boots and gloves) is essential at the time of application. In the present study, it was found that only $28 \%(28 / 100)$ of the properties use complete PPE, and 41\% (41/100) used some PPE at the time of application, with the glove being the most cited PPE (33\%). Small-scale production properties differed in response, being 48.7\% (19/39) of respondents said they did not use any PPE during the application of the acaricide. The hypothesis for this difference 
is that in small-scale properties there are few workers, and the person responsible for the application becomes familiar with the activity, believing that the use of PPE is not necessary. According to Furlong et al. (2007), when the employee frequently has contact with the product, they tend to decrease the care needed when handling these toxic substances.

Santos et al. (2000) observed an excessive and inefficient use of chemical acaricide to control Rhipicephalus (Boophilus) microplus during their research, leading to risks of contamination of the environment, poisoning and development of resistant tick strains. The author emphasizes the need for convincing campaigns to implement strategic control measures, including operator safety with the use of PPE's.

When asked about their knowledge of other forms of tick control, 83\% (83/100) of the interviewees said they knew about it, the most cited being the vaccine and pour-on products. No producer cited biological control or strategic control. Demonstrating more than a decade of the study by Rocha et al. (2006), the conclusions are the same; few producers in South Minas Gerais are aware of strategic tick control or biological control.

The grace periods for each product for later use of milk must be respected to ensure food security. The efficiency of the acaricide used on an annual basis or whenever suspected of failures should be assessed using samples of adult ticks (engorged females - teleogens) and sent to prepared laboratories. In Brazil, there is a network of accredited laboratories that routinely perform in vitro sensitivity profile of dairy cattle ticks to commercial acaricides. This practice leads to a reduction in animal stress and labor costs, environmental preservation and minimizing residues in products derived from treated animals, increasing quality and adding value to them. The delay in the resistance process ensures longer use of the few chemical bases available (Andreotti et al., 2019).

\section{Conclusions}

The majority of milk producers interviewed in the present study used antiparasitic drugs with restricted use in lactating dairy cows because it presented a more effective control against ectoparasites.

Small-scale production properties promote empirical practices of using acaricides, favoring the appearance of resistance, residues in milk products and practices that put the health of the worker at risk. However, all the properties, regardless of the scale of production, demonstrated that they did not adopt technical criteria for the control of ticks, had little information on other forms of control and were unconcern with the use of inappropriate acaricides and worker safety.

In order to revert this antiparasitic drug's resistance situation and contamination of milk with drug residues, it is necessary to focus on the awareness of milk producers and training of labor.

\section{References}

Andreotti R, Garcia MV, Koller WW. Carrapatos na cadeia produtiva de bovinos. Brasília: EMBRAPA Press; 2019.

Bastos LHP, Cardoso MHWM, Nóbrega AW, Jacob SDC. Possíveis fontes de contaminação do alimento leite, por agrotóxicos, e estudos de monitoramento de seus resíduos: uma revisão nacional. Cad Saude Colet 2011; 19(1): 51-60.

Bertolucci AV. Percepção dos produtores do sul de Minas Gerais sobre a importância e forma de controle do carrapato Rhipicephalus (Boophilus) microplus (Canestrini, 1887) [dissertação]. Lavras: Universidade Federal de Lavras; 2011.

Biegelmeyer P, Nizoli LQ, Cardoso FF, Dionello NJL. Aspectos da resistência de bovinos ao carrapato Rhipicephalus (Boophilus) microplus. Arch Zootec 2012; 61(R): 1-11.

Bull MS, Swindale S, Overend D, Hess EA. Suppression of Boophilus microplus populations with fluazuron-an acarine growth regulator. Aust Vet J 1996; 74(6): 468-470. http://dx.doi.org/10.1111/j.1751-0813.1996.tb07575.x. PMid:9006870.

Campos DA Jr, Oliveira PR. Avaliação in vitro da eficácia de acaricidas sobre Boophilus microplus (Canestrini, 1887) (Acari: Ixodidae) de bovinos no município de Ilhéus, Bahia, Brasil. Cienc Rural 2005; 35(6): 1386-1392. http://dx.doi.org/10.1590/S010384782005000600025 .

de Oliveira PR, Calligaris IB, Roma GC, Bechara GH, Camargo-Mathias MI. Fluazuron-induced morphophysiological changes in the cuticle formation and midgut of Rhipicephalus sanguineus Latreille, 1806 (Acari: Ixodidae) nymphs. Parasitol Res 2013; 112(1): 45-58. http://dx.doi.org/10.1007/s00436-012-3103-7. PMid:22992894.

Empresa Brasileira de Pesquisa Agropecuária - EMBRAPA. Anuário do Leite 2019 [online]. 2019 [cited 2019 Oct 8]. Available from: https://cutt.ly/Kfe59mM 
Empresa Brasileira de Pesquisa Agropecuária - EMBRAPA. Carrapato dos bovinos: controle estratégico nas diferentes regiões brasileiras [online]. 2003 [cited 2019 Sep 11]. Available from: https://cutt.ly/WffHfh8

Empresa Brasileira de Pesquisa Agropecuária - EMBRAPA. Resistência dos carrapatos aos carrapaticidas [online]. 2000 [cited 2019 Sep 11]. Available from: https://cutt.ly/6ffH1cZ

Faria VP, Corsi M. Índices de produtividade em gado de leite. In: Peixoto AM, Moura JC, Faria VP, editors. Bovinocultura leiteira: fundamentos da exploração racional. 2nd ed. Piracicaba: FEALQ; 1993. p. 1-22.

Fernández-Salas A, Rodríguez-Vivas RI, Alonso-Díaz MA, Basurto-Camberos H. Ivermectin resistance status and factors associated in Rhipicephalus microplus (Acari: Ixodidae) populations from Veracruz, Mexico. Vet Parasitol 2012; 190(1-2): 210-215. http://dx.doi. org/10.1016/j.vetpar.2012.06.003. PMid:22785128.

Fraga AB, Alencar MM, Figueiredo LA, Razook AG, Cyrillo JNSG. Análise de fatores genéticos e ambientais que afetam a infestação de fêmeas bovinas da raça Caracu por carrapatos (Boophilus microplus). Rev Bras Zootec 2003; 32(6 Suppl 1): 1578-1586. http:// dx.doi.org/10.1590/S1516-35982003000700006.

Furlong J, Martins JRS, Prata MCA. O carrapato dos bovinos e a resistência: temos o que comemorar? Hora Vet 2007; 27(159): 1-7.

Gil AC. Métodos e técnicas de pesquisa social. São Paulo: Atlas; 1991.

Grisi L, Leite RC, Martins JRS, Barros ATM, Andreotti R, Cançado PHD, et al. Reassessment of the potential economic impact of cattle parasites in Brazil. Rev Bras Parasitol Vet 2014; 23(2): 150-156. http://dx.doi.org/10.1590/S1984-29612014042. PMid:25054492.

Hernandes T, Goulart MA, Dores EFGC, Prado M, Malm O. Manejo Sanitário do rebanho leiteiro e resíduos de inseticidas Piretróides em leite de vaca produzido no município de Chapada dos Guimarães, Brasil. Acta Sci Vet 2009; 37(2): 171-176. http:// dx.doi.org/10.22456/1679-9216.16246.

Higa LOS, Garcia MV, Rodrigues VDS, Bonatte-Junior P, Barradas-Piña FT, Barros JC, et al. Effects of cypermethrin, chlorpyrifos and piperonyl butoxide-based pour-on and spray acaricides on controlling the tick Rhipicephalus microplus. Syst Appl Acarol 2019; 24(2): 278-286. http://dx.doi.org/10.11158/saa.24.2.10.

Instituto Brasileiro de Geografia e Estatística - IBGE. Censo Agropecuário 2017 [online]. Rio de Janeiro: IBGE; 2017 [cited 2019 Aug 19]. Available from: https://cutt.ly/JffLWOC

Jonsson NN, Matschoss AL. Attitudes and practices of Queensland dairy farmers to the control of the cattle tick, Boophilus microplus. Aust Vet J 1998; 76(11): 746-751. http://dx.doi.org/10.1111/j.1751-0813.1998.tb12306.x. PMid:9862066.

Le Faouder J, Bichon E, Brunschwig P, Landelle R, Andre F, Le Bizec B. Transfer assessment of fipronil residues from feed to cow milk. Talanta 2007; 73(4): 710-717. http://dx.doi.org/10.1016/j.talanta.2007.04.061. PMid:19073092.

Leal AT, Freitas DRJ, Vaz Júnior IS. Perspectivas para o controle do carrapato bovino. Acta Sci Vet 2003; 31(1): 1-11. http://dx.doi. org/10.22456/1679-9216.16965.

Lemos AM, Teodoro RL, Oliveira GP, Madalena FE. Comparative performance of six Holstein-Friesian x Guzera Grades in Brazil 3. Burdens of Boophilus microplus under field conditions. Anim Sci 1985; 41(2): 187-191. http://dx.doi.org/10.1017/ S0003356100027847.

Li AY, Chen AC, Miller RJ, Davey RB, George JE. Acaricide resistance and synergism between permethrin and amitraz against susceptible and resistant strains of Boophilus microplus (Acari: ixodidae). Pest Manag Sci 2007; 63(9): 882-889. http://dx.doi. org/10.1002/ps.1417. PMid:17665370.

Lopes MA, Lima ALR, Carvalho FM, Reis RP, Santos IC, Saraiva FH. Efeito da escala de produção nos resultados econômicos de sistemas de produção de leite na região de Lavras (MG): um estudo multicasos. Bol Ind Anim 2006; 63(3): 177-188.

Madalena FE, Peixoto MGCD, Gibson J. Dairy cattle genetics and its applications in Brazil. Livest Res Rural Dev 2012; $24(6): 97$.

Mendes MC, Lima CK, Nogueira AH, Yoshihara E, Chiebao DP, Gabriel FH, et al. Resistance to cypermethrin, deltamethrin and chlorpyriphos in populations of Rhipicephalus (Boophilus) microplus (Acari: Ixodidae) from small farms of the State of São Paulo, Brazil. Vet Parasitol 2011; 178(3-4): 383-388. http://dx.doi.org/10.1016/j.vetpar.2011.01.006. PMid:21306827.

Miller RJ, Almazán C, Ortíz-Estrada M, Davey RB, George JE, De León AP. First report of fipronil resistance in Rhipicephalus (Boophilus) microplus of Mexico. Vet Parasitol 2013; 191(1-2): 97-101. http://dx.doi.org/10.1016/j.vetpar.2012.08.011. PMid:23026557.

Minayo MCS. O desafio do conhecimento: pesquisa qualitativa em saúde. São Paulo: HUCITEC - ABRASCO; 1993.

Miranda JEC, Freitas AF. Raças e tipos de cruzamento para produção de leite. Juiz de Fora: Embrapa Gado de Leite; 2009. (Circular Técnica; vol. 98).

Pereira MC, Labruna MB. Rhipicephalus (boophilus) microplus. In: Pereira MC, Labruna MB, Szabó MPJ, Klafke GH. Rhipicephalus (Boophilus) microplus: biologia, controle e resistência. São Paulo: MEDVET; 2008. 
Reck J, Klafke GM, Webster A, Dall'Agnol B, Scheffer R, Souza UA, et al. First report of fluazuron resistance in Rhipicephalus microplus: a field tick population resistant to six classes of acaricides. Vet Parasitol 2014; 201(1-2): 128-136. http://dx.doi.org/10.1016/j. vetpar.2014.01.012. PMid:24560364.

Rocha CMBM, Oliveira PR, Leite RC, Cardoso DL, Calic SB, Furlong J. Percepção dos produtores de leite do município de Passos, MG, sobre o carrapato Boophilus microplus (Acari: Ixodidae), 2001. Cienc Rural 2006; 36(4): 1235-1242. http://dx.doi.org/10.1590/ S0103-84782006000400029.

Rocha CMBM. Caracterização da percepção dos produtores de leite do município de Divinópolis/MG sobre a importância do carrapato Boophilusmicroplus e fatores determinantes das formas de combate utilizadas [dissertação]. Minas Gerais: Universidade Federal de Minas Gerais; 1995.

Rodrigues DS, Leite RC. Economic impact of Rhipicephalus (Boophilus) microplus: estimate of decreased milk production on a dairy farm. Arq Bras Med Vet Zootec 2013; 65(5): 1570-1572. http://dx.doi.org/10.1590/S0102-09352013000500039.

Rodrigues VS, Bonatte P Jr, Garcia MV, Higa LOS, Piña FTB, Zimmermann NP, et al. Efficacy profile of Cypermethrin and Chlorpyrifos based acaricides on Rhipicephalus microplus control on cattle in the rearing phase, naturally infested and exposed to tick fever agents in central Brazil. Vet Parasito/ Reg Stud Reports 2018; 12: 43-48. http://dx.doi.org/10.1016/j.vprsr.2018.02.001. PMid:31014808.

Rodríguez-Vivas RI, Pérez-Cogollo LC, Rosado-Aguilar JA, Ojeda-Chi MM, Trinidad-Martinez I, Miller RJ, et al. Rhipicephalus (Boophilus) microplus resistant to acaricides and ivermectin in cattle farms of Mexico. Rev Bras Parasitol Vet 2014; 23(2): 113-122. http:// dx.doi.org/10.1590/S1984-29612014044. PMid:25054487.

Santana VLA. Situação do controle químico do Boophilus microplus (Canestrini, 1887) das subregiões na zona da mata e agreste do estado de Pernambuco, com base em testes in vitro de eficácia de carrapaticidas em fêmeas ingurgitadas [dissertação] Pernambuco: Universidade Federal Rural de Pernambuco; 2000.

Santos JCB Jr, Furlong J, Daemon E. Controle do carrapato Boophilus microplus (Acari: Ixodidae) em sistemas de produção de leite da microrregião fisiográfica fluminense do grande Rio - Rio de Janeiro. Cienc Rural 2000; 30(2): 305-311. http://dx.doi. org/10.1590/S0103-84782000000200018.

Sindicato Nacional da Industria de Produtos Para Saúde Animal - SINDAN. Compêndio de Produtos Veterinários [online]. São Paulo: SINDAM-MAPA; 2017 [cited 2021 Mar 04]. Available from: https://sistemas.sindan.org.br/

Spagnol FH, Paranhos EB, Albuquerque GR. Avaliação in vitro da ação de acaricidas sobre Rhipicephalus (Boophilus) microplus Canestrini, 1887 (Acari: Ixodidae) de bovinos leiteiros no município de Itamaraju, Bahia, Brasil. Cienc Anim Bras 2010; 11(3): 731736. http://dx.doi.org/10.5216/cab.v11i3.8149.

Stafuzza NB, Zerlotini A, Lobo FP, Yamagishi MEB, Chud TCS, Caetano AR, et al. Single nucleotide variants and InDels identified from whole-genome re-sequencing of Guzerat, Gyr, Girolando and Holstein cattle breeds. PLoS One 2017; 12(3): e0173954. http:// dx.doi.org/10.1371/journal.pone.0173954. PMid:28323836.

Veríssimo CJ, Vasques F, Duarte KMR, Paulino VT, Ambrósio LA. Management and control of parasites on dairy farms in northwestern region of São Paulo state. Rev Bras Parasitol Vet 2016; 25(3): 306-316. http://dx.doi.org/10.1590/S1984-29612016050. PMid:27580398.

Whelan M, Kinsella B, Furey A, Moloney M, Cantwell H, Lehotay SJ, et al. Determination of anthelmintic drug residues in milk using ultra high performance liquid chromatography-tandem mass spectrometry with rapid polarity switching. J Chromatogr $A$ 2010; 1217(27): 4612-4622. http://dx.doi.org/10.1016/j.chroma.2010.05.007. PMid:20564781.

Yessinou RE, Akpo Y, Adoligbe C, Adinci J, Assogba MN, Koutinhouin B, et al. Resistance of tick Rhipicephalus (Boophilus) microplus to acaricides and control strategies. J Entomol Zool Stud 2016; 4(6): 408-414. 